\title{
7
}

\section{Observation and Research on the Typical Atmosphere of Beijing Olympic Games by Optical Remote Sensing}

\author{
Wenqing Liu, Wei Huang, Pinhua Xie and Jianguo Liu \\ State Environmental Protection Key Laboratory of Optical Monitoring Technology, \\ Ministry of Environmental Protection of the People's Republic of China, \\ Anhui Institute of Optics \& Fine Mechanics, Chinese Academy of Sciences, Hefei, Anhui \\ P.R. China
}

\section{Introduction}

The 29th Olympic and Paralympics Games were held from August $8^{\text {th }}$ to September $17^{\text {th }}$, 2008 in China's capital - Beijing. Air quality is a critical concern to China and the world. To ensure good air quality during the Olympic Games, Beijing Municipal Government and the Environmental Protection Agency of China launched a program called "Air Quality Guarantee Plan for the 29th Olympics in Beijing (AQGP)". The period starting from July 1st, 2008 marked an intensified endeavour to improve Beijing's air quality by shutting down heavy polluters. 3.3 million motor vehicles were removed from city streets on alternate days, depending on whether the license plate ended in an odd or even number during the period of July $20^{\text {th }}$ to Sep. $20^{\text {th }}, 2008$ (the alternative day-driving scheme). At the same time, the adjacent cities and provinces also did their best to close major polluters that may have influence on the air quality of Beijing. The exceptional strict pollution control measures have hugely reduced the source emissions, making a green Olympic Games achievable. Beijing's air quality has witnessed significant improvements due to enhanced pollution control efforts and new environment criteria.

Beijing's air quality was intensively monitored by environment protection authorities and research institutions before, during, and after the Olympic Games. The rich scientific data collected during the period have become solid evidences for judging the impact of exposure to air pollution on human health. To evaluate the effectiveness of the AQGP program, Beijing Municipal Environmental Protection Agency led a plan named "Assessment of AQGP and Air quality Monitoring, Forecasting and Early Warning".

There are numerous publications (Cermak \& Knutti, 2009; Huang et al., 2010; Y. Li et al., 2010; X. G. Liu et al., 2009; Mijling et al., 2009; Shao et al., 2009; Shen et al., 2011; Shou-bin et al., 2009; Simonich, 2009; Streets et al., 2007; X. Y. Tang et al., 2009; W. T. Wang et al., 2009; Westerdahl et al., 2009; Yao et al., 2009) to now on evaluation of these pollution measures. Hou. et. al. (Hou et al., 2010) measured the levels of Beijing residents' exposure to $\mathrm{PM}_{10}$ during three different time periods. Their study showed that during the Olympic Games, population-weighted $\mathrm{PM}_{10}$ exposure came down by $46 \%$ and $19 \%$, respectively, compared with the pre-OG and the post-OG periods, indicating that in addition to favourable weather 
conditions, enhanced traffic and emission control policies and measures have produced a noticeable effect on $\mathrm{PM}_{10}$ reduction.

For persistent organic pollutants (POPs), Zhang et. al. (L. F. Zhang et al., 2010) systematic studied hexachlorobenzene in the ambient air before and after the Olympic Games. Hexachlorobenzene concentration was found decreased sharply in the winter of 2008 comparing with that of 2007 due to the implementation of a series of "Green Olympic" policies. Gas-particle partitioning shows that the increase of hexachlorobenzene levels in winter time was mainly contributed by the high total suspended particulate from combustion processes such as coal-burning and traffic emission.

Xin et. al. (Xin et al., 2010) used Beijing-Tianjin-Hebei Atmospheric Environment Monitoring Network to monitor and provide warnings of the atmospheric quality in Beijing and its surrounding area during the Beijing 2008 Olympic Games. During the Olympic Games, the mean concentration of $\mathrm{SO}_{2}, \mathrm{PM}_{2.5}, \mathrm{NO}_{2}, \mathrm{O}_{3} \_$h $\max$, and $\mathrm{O}_{\mathrm{x}}$ were $12.5 \pm 4,56 \pm 28,23 \pm 4,114 \pm 29$, $95 \pm 17 \mu \mathrm{g} / \mathrm{m}^{3}$ in the region, respectively, and fell by $51.0 \%, 43.7 \%, 13 \%, 20.2 \%$, and $18.9 \%$, respectively, compared to the prophase mean concentration before the Olympic Games. After the Olympic Games, $\mathrm{SO}_{2}, \mathrm{PM}_{2.5}$ and $\mathrm{NO}_{x}$ increased significantly as the temporary atmospheric pollution control measures was terminated. Wang et. al's study (S. X. Wang et $a l ., 2010)$ showed that the mobile source NOx and non-methane volatile organic compounds (NMVOC) reduced by $46 \%$ and $57 \%$, respectively, during the Olympic Games period due to strict pollution policies.

Zhou et. al. investigated the effects of pollution measures on urban motor vehicle emissions in Beijing. (Zhou et al., 2010) Comparison between the emission intensity before and during the 2008 Olympics shows a reduction of $44.5 \%$ and $49.0 \%$ in daily CO and NOx emission from motor vehicles. Their results suggest that reasonable traffic system improvement strategies along with vehicle technology improvements can contribute to controlling total motor vehicle emissions in Beijing after the Olympic Games. Wang et. al. (Wang \& Xie, 2009) investigated the traffic-related air pollution in the urban streets. The average reduction of $\mathrm{PM}_{10}, \mathrm{CO}, \mathrm{NO}_{2}$ and $\mathrm{O}_{3}$ are $28 \%, 19.3 \%, 12.3 \%$, and $-25.2 \%$, respectively. Another study (X. Wang et al., 2009) evaluated on-road emission factors and black carbon profiles. Diesel trucks are believed to be a major source of summertime BC in Beijing. A mobile laboratory(M. Wang et al., 2009) also was employed to evaluate changes in on-road air pollutants.

Liu et. al. (J. F. Liu et al., 2009) measured the hourly concentrations of BTEX (Benzene, Toluene, Ethylbenzene, m,p-Xylene and o-Xylene) in the urban area of Beijing. They found that during the games, the mean daytime concentrations of benzene, toluene, ethylbenzene, $\mathrm{m}, \mathrm{p}$-xylene and o-xylene were 2.37, 3.97, 1.92, 3.51 and $1.90 \mu \mathrm{g} / \mathrm{m}^{3}$, respectively, and were $52.8 \%, 63.9 \%, 56.4 \%, 56.8 \%$, and $46.9 \%$ lower than those after the games. Secondary pollutants and regional impact also were studied. (T. Wang et al., 2010)

He et. al. (S. Z. He et al., 2010) measured atmospheric $\mathrm{H}_{2} \mathrm{O}_{2}$ and organic peroxides in urban Beijing (at the Peking University campus), from $12^{\text {th }}$ July to $30^{\text {th }}$ September, before and during the Beijing Olympic Games full-scale control. They concluded that the heterogeneous removal of $\mathrm{H}_{2} \mathrm{O}_{2}$ is faster than that of methyl hydroperoxide (MHP), as indicated by the strong negative correlation between the $\mathrm{H}_{2} \mathrm{O}_{2}$-to-MHP ratio and the aerosol surface area.

Wang. et. al. (B. Wang et al., 2010) assessed variation of ambient non-methane hydrocarbons by gas chromatography equipped with a quadrupole mass spectrometer and a flame ionization detector (GC/MSD/FID) as parts of the field Campaign for the Beijing Olympic Games Air Quality program (CareBeijing). Their findings demonstrate the effectiveness of 
the air quality control measures enacted for the 2008 Olympics and indicate that controlling vehicular emissions could be the most important measure to improve the air quality of Beijing.

The abovementioned studies used all kinds of methods to evaluate the air quality during Beijing Olympic Games, but nearly none used optical remote sensing methods. Here we will introduce our investigations on the air quality of Beijing Olympic Games using all kinds of optical remote sensing techniques. Due to the limited room in this chapter, we will only introduce part of our results here.

The emission flux of important pollution sources was measured with mobile differential optical absorption spectroscopy (DOAS) and light detection and ranging (LIDAR). The sources are Capital Iron and Steel (CIS), Yanshan Petrochemical (YP), and Capital Airport (CA), respectively. It was found that CIS contributed most to emissions of $\mathrm{NO}_{2}, \mathrm{SO}_{2}$, and particulate matter, but the overall emission flux from June to September was decreasing, representing the effectiveness of air pollution control policy. It was also found that the emission flux came from YP declined as well, while the $\mathrm{NO}_{2}$ emission of CA only had a slight drop.

The MAX-DOS system located in the region of pollution sources monitored the tropospheric column density of $\mathrm{SO}_{2}$ and $\mathrm{NO}_{2}$, which reflected the whole layer concentration of $\mathrm{SO}_{2}$ and $\mathrm{NO}_{2}$ around pollution sources. The results showed that the column density of $\mathrm{SO}_{2}$ and $\mathrm{NO}_{2}$ of CIS, YP and $\mathrm{SO}_{2}$ decreased significantly, where the column density of $\mathrm{NO}_{2}$ of CIS and YP decreased by $30-40 \%$, whereas that of CA reduced less.

LIDAR measurements proved that emissions of particulate matter can be reduced to some extent by the alternative day-driving scheme and plant production restriction. Weather is the major factor for cleaning of particulate matters, implying that the emission control policy can only reduce the accumulation of pollutant in some extent, but the decisive factor of pollutant elimination is still weather.

The observation to 4 main pollutants $\left(\mathrm{SO}_{2}, \mathrm{NO}_{2}, \mathrm{CO}, \mathrm{PM}_{10}\right)$ in all stations showed their concentration reached the China National Level II Standard and the guideline values of WHO. The concentration of $\mathrm{NH}_{3}$ was found to be higher in the daytime while lower during the night-time. Varieties of optical remote sensing techniques were used to monitor the air quality of 2008 Beijing Olympic Games, and were proved to be critical in air quality monitoring system.

The tropospheric nitrogen dioxide over the Beijing Olympic Games venues was measured by ground-based Multi Axis Differential Optical Absorption Spectroscopy (MAX-DOAS), and was compared with the result of Ozone Monitoring Instrument (OMI) (Duncan et al., 2010). It showed that the results of MAX-DOAS were higher than that of OMI, and can up to 2.4 times the result of OMI; both instruments had good correlation $(r=0.64)$ when it is clear. There was more difference between the results of both instruments for the existing of cloud when it was rainy or cloudy, with a correlation coefficient of 0.19 , but the results of MAXDOAS had better consistency with LP-DOAS, with a correlation coefficient of 0.92 .

\section{Experimental methods - optical remote sensing}

An integrated spatiotemporal monitoring system (Fig. 1) for regional complex air pollution was constructed which comprises a variety of optical remote sensing techniques, such as differential optical absorption spectroscopy (DOAS)(Winer \& Biermann, 1994), light detection and ranging (LIDAR)(Vierling et al., 2008), Fourier transform infrared 
spectroscopy (FTIR)(Movasaghi et al., 2008), tunable diode laser absorption spectroscopy (TDLAS) (Lackner, 2007), tapered element oscillating microbalance (TEOM) (Patashnick \& Rupprecht, 1991). It was worth pointing out that all the instruments mentioned here were developed in our institute (Chen et al., 2009; He et al., 2009; Y. B. He et al., 2010; Jin et al., 2010; S. W. Li et al., 2009; S. W. Li et al., 2008; Lu et al., 2010a, 2010b; Luo et al., 2011; Si et al., 2010; Y. Y. Tang et al., 2010; J. Xu et al., 2010; Z. Y. Xu et al., 2010; S. A. Zhang et al., 2009; Zhu et al., 2010). We established 11 monitoring stations including 3 super monitoring stations and 2 mobile monitoring vehicles. From June 10th to September $20^{\text {th }}$ of 2008 , the air quality of Beijing area was monitored continuously and in real-time at these stations. Enormous data on all kinds of pollutants were acquired to assess the consequences of air pollution source control policies implied during the Olympic Games.

\section{Experimental results and discussions}

The integrated spatiotemporal monitoring system consists of 11 monitoring stations equipped with a variety of aforementioned optical remote sensing instruments. There are 3 super monitoring stations and 2 mobile monitoring vehicles. Air quality of Beijing area was monitored continuously and in real-time in these stations from June $10^{\text {th }}$ to September $20^{\text {th }}$, Enormous data on all kinds of pollutants were acquired to assess the consequences of air pollution source control policies implied during the Olympic Games. Here we will choose some typical data to demonstrate applications of optical remote sensing techniques.

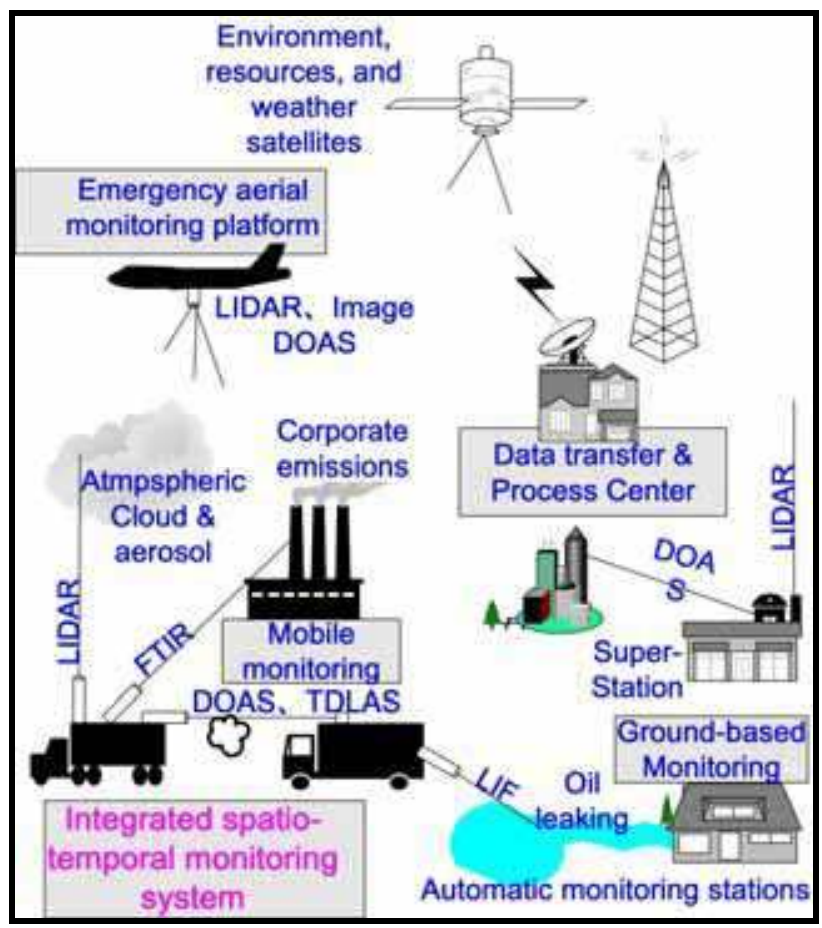

Fig. 1. Integrated spatiotemporal monitoring system for regional complex air pollution 


\subsection{Aerosol extinction \& backscattering coefficients}

We've done continuously measurements to air quality over the Olympic Games main sports center - "Bird's Nest" using double wavelength Raman LIDAR with three channels. The Raman LIDAR was installed at the Institute of Remote Sensing Applications (IRSA), Chinese Academy of Sciences, which is located about 500 meters north of the "Bird's Nest". The data acquired from Raman LIDAR are used to analyze the optical characteristics of representative weather during the period of Olympic Games.

Fig. 2 shows the aerosol extinction coefficient spatial and temporal distributions during Aug. $7^{\text {th }}-$ Aug. 25th 2010 . Obviously, one can find that the aerosol extinction coefficients on Aug. $8^{\text {th }}$ and Aug. $9^{\text {th }}$ are considerably large, suggesting pretty heavy air pollution, and thereafter the atmosphere became clear due to several rainfalls.

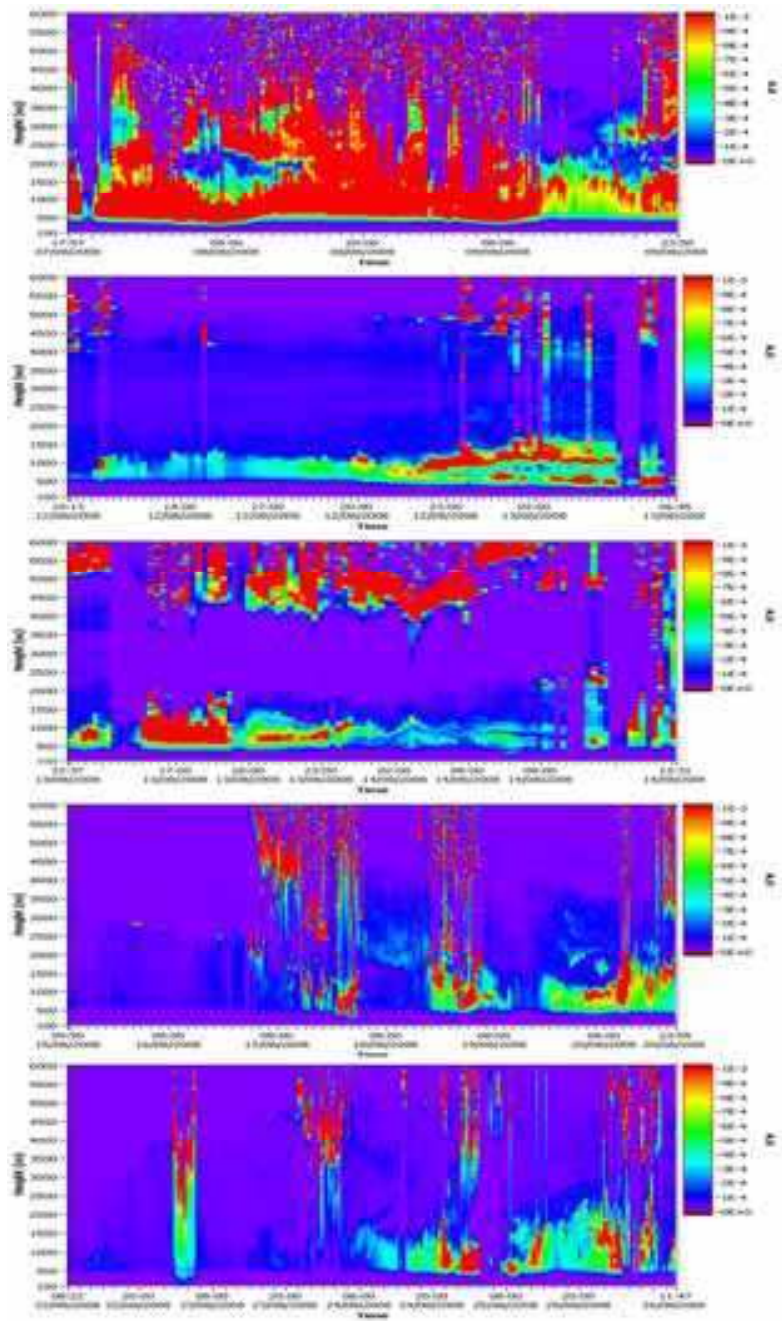

Fig. 2. Aerosol extinction coefficient vertical distributions during Aug. $7^{\text {th }} \sim 25^{\text {th }}$, 2008 
The aerosol extinction coefficient at some wavelength can give the distribution of pollutants, but it cannot provide the particle size information. Fig. 3 shows the spatial and temporal distribution of backscatter signal and extinction coefficient at $355 \mathrm{~nm} \& 532 \mathrm{~nm}$ from Aug. $7^{\text {th }}$ to $9^{\text {th }}, 2010$. As can be seen from the figure, the backscatter signals at $355 \mathrm{~nm}$ and $532 \mathrm{~nm}$ illustrate the spatial distribution of small aerosol particles clearly, and the heights of most of these small particles are lower than 600 meters. The most abundant distribution is at $\sim 400$ meters, and this is verified by the ratio of aerosol extinction coefficients at two different wavelengths. The height distribution and diurnal change of boundary layer are clearly demonstrated in the spatial -temporal distribution (Fig. 3).

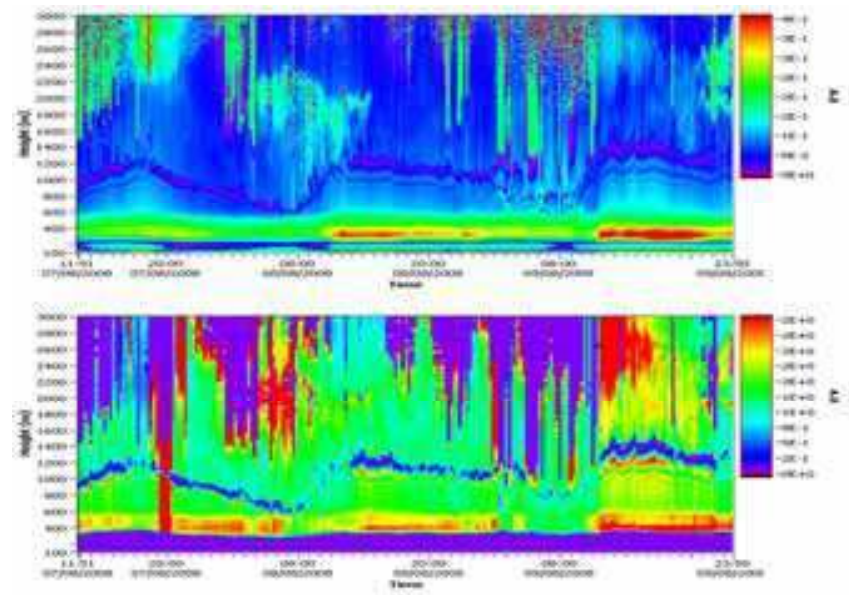

Fig. 3. Ratio vertical distribution of backscatter signal (upper pannel) and extinction coefficient (lower pannel) of 355/532 nm from Aug. $7^{\text {th }}$ to $9^{\text {th }}, 2008$

It is worth noting that Yang (Yang et al., 2010) also used a Dual-wavelength Polarized LIDAR to analyzes the variation of aerosol extinction coefficients during the Beijing Olympic Games. Their results showed that (1) during the Beijing Olympic Games, the aerosol extinction coefficient decreased to about $42.3 \%$ in the surface layer (below $250 \mathrm{~m}$ ) compared with that in 2007 under almost the same meteorological conditions, indicating the effectiveness of local air pollution control measures in Beijing areas; (2) the analysis of the aerosol extinction coefficient obtained before (Jul. 20th-Aug. $7^{\text {th }}, 2008$ ) and during the Beijing Olympic Games (Aug. 8th-Aug. 24th 2008) shows a maximum decrease of daily aerosol extinction coefficient in the layer of $0.5-1.5 \mathrm{~km}$. To elucidate such a phenomenon, the transport of $\mathrm{PM}_{10}$ from surrounding areas to Beijing was simulated by NAQPMS (the Nested Air Quality Prediction Modeling System) for the period from Jul. 20th to Aug. 24th, 2008. Analysis of $\mathrm{PM}_{10}$ transport from neighboring areas indicated a decrease of $36.6 \%$ during the Olympic Games.

Aerosol optical depth (AOD) is a manifestation of air pollution to some extent, and angstrom wavelength exponent (AE) is an indicator of the relative size of aerosol particles. Fig. 4 illustrates the distribution of aerosol optical depth and angstrom exponent between Aug. $7^{\text {th }}$ and Aug. 25th 2010. One can clearly see that the AODs in the first 3 days are large,

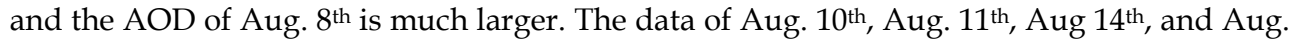
$21^{\text {st }}$ are missed due to rains in these days. According to the variations of AOD, we found 
that the AOD rose significantly after rainfalls, hinting a procedure of pollutants accumulation. The average Angstrom exponents calculated from Fig. 4 is 2.64. Fig. 4 shows that the heavy pollution on Aug 8th-9th is caused by large aerosol particles. The AEs are very small after the rainfalls on Aug 14th and Aug. 21 ${ }^{\text {st }}$, meaning the average aerosol particle size is small, and this agrees well with other atmospheric fine particle size measurements.

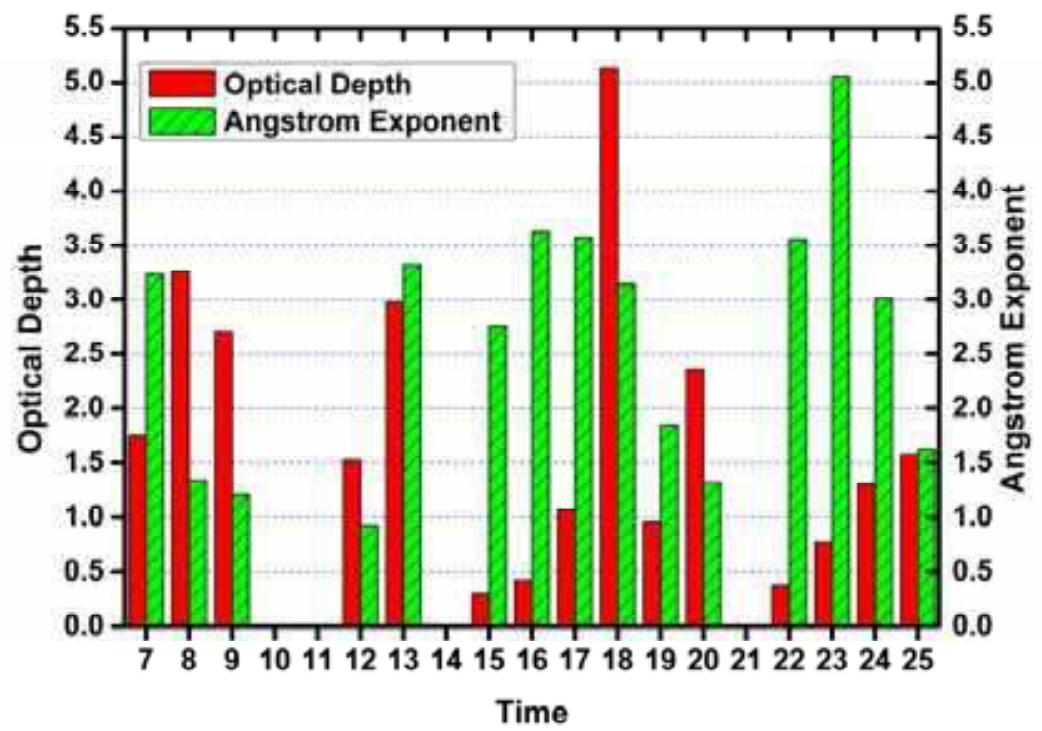

Fig. 4. Distribution of aerosol optical depth and Angstrom exponent during 20:00 23:59 during Aug. $7^{\text {th }} \sim 25^{\text {th }}, 2008$

From the measurements of Raman LIDAR, it was concluded that: (a) the distribution of pollutants on Aug 7-9th exhibits period variation with time, and the heavy pollution on Aug. 8-9th is attributed to large aerosol particles; (b) The echo signals of LIDAR at different wavelengths clearly depicts the spatial distribution of aerosol particle size. The altitude of most small particles is about 400 meters. The AOD become much larger after rains, suggesting an accumulation process of pollutants; (c) the average AE is 2.64 during the period of Olympic Games, and its diurnal changes are in very good agreement with the data of ground-based atmospheric fine particle measurement.

\subsection{Measurement of $\mathrm{SO}_{2}, \mathrm{NO}_{2}, \mathrm{O}_{3}$ and $\mathrm{PM}_{10}$}

5 of the 11 monitor stations are used to measure the conventional pollutants in Beijing and surrounding areas. These stations are located in Yanshan Petrochemical (YP), Yugang Town (YT), Institute of Remote Sensing Applications, Chinese Academy of Sciences (IRSA), Capital Airport (CA), and Yongledian Town (YLD), respectively. The concentration of gaseous pollutants, i.e., $\mathrm{SO}_{2}, \mathrm{NO}_{2}$, and $\mathrm{O}_{3}$, was measured using DOAS. We tested the performance of the DOAS system and calibrateed the lamp spectra every day. The comparison of these data with other instruments in IRSA and YP was used to ensure the accuracy and reliability of field measurements. TEOM was used to get the $\mathrm{PM}_{10}$ data. The 
measurements started from Jun. 20, of 2008, and ended in September, 2008. We will introduce the time series, average diurnal change, regional transport, and comparison of pollutant concentration in YP, YT, IRSA, and CA.

\subsubsection{Time series of pollutant concentration}

Fig. 5 is the hourly average time series of pollutants. The $\mathrm{PM}_{10}$ concentration of IRSA station is much higher than that of YT because IRSA is very close to the Bird's Nest, and there were more human activities near this station, while YT is in suburb area. The maximum concentration of $\mathrm{PM}_{10}$ in IRSA station occurred at 13:00, July $4^{\text {th }}$, and is $470.6 \mu \mathrm{g} / \mathrm{m}^{3}$. The maximum concentration of $\mathrm{PM}_{10}$ in YT station occurred at 22:00, July 27th, and is 354.0 $\mu \mathrm{g} / \mathrm{m}^{3}$. The sources of $\mathrm{PM}_{10}$ are very complicated, e.g., coal and dust pollution, industrial emissions, vehicle emissions, and pollutants transport. The weak southerly wind from July $4^{\text {th }}$ to Aug. 10 th hindered the diffusion of pollutants, and made the concentrations of $\mathrm{PM}_{10}$ and $\mathrm{O}_{3}$ measured in each station are pretty high.

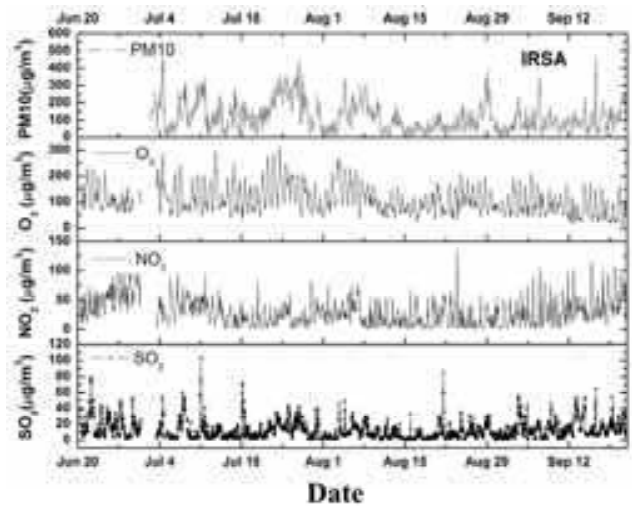

(a)

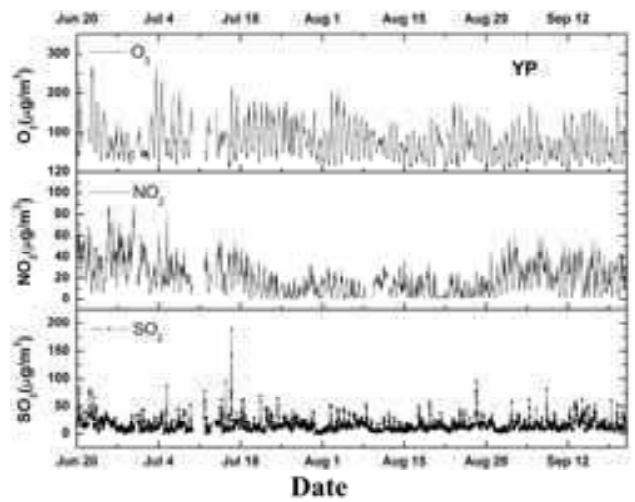

(c)

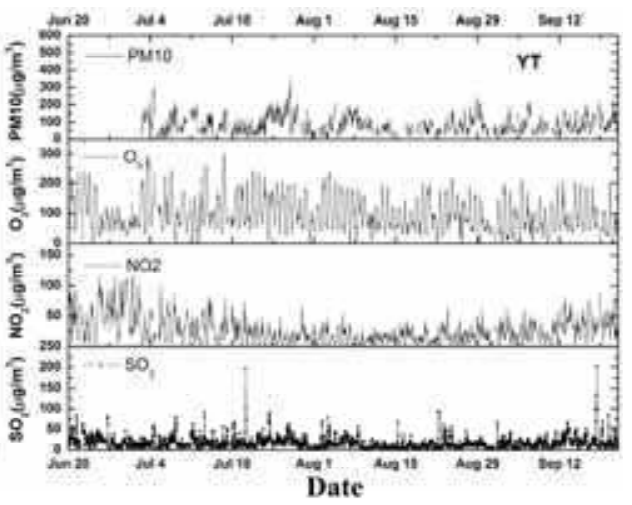

(b)

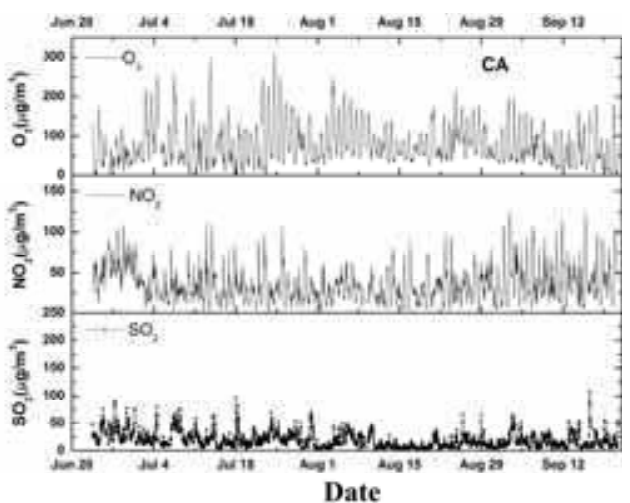

(d)

Fig. 5. Time series of observed SO2, NO2, O3 and PM10

$\mathrm{O}_{3}$ came from the photochemical reactions during the daytime, and exhibited apparent diurnal variation trend, i.e., the peak value occurred in the afternoon, as the valley 
happened in the night. The maximum hourly average $\mathrm{O}_{3}$ concentration occurred at 13:00, Jun. 22nd in IRSA station, and the value is $324 \mu \mathrm{g} / \mathrm{m}^{3}$. The concentrations of $\mathrm{SO}_{2}$ and $\mathrm{NO}_{2}$ were under the requirement of National Atmosphere Environment Quality Level II, which are $500 \mu \mathrm{g} / \mathrm{m}^{3}$ and $120 \mu \mathrm{g} / \mathrm{m}^{3}$. The main source of $\mathrm{SO}_{2}$ came from combustion of sulfur compounds. The peak values of $\mathrm{SO}_{2}$ concentration were more frequently found in $\mathrm{YP}$ and YT stations. $\mathrm{NO}_{2}$ was found to have a contrary trend with $\mathrm{O}_{3}$ in concentration change, i.e., the concentration was high during the night, but became lower in the day due to low photolysis concentration. There are lots of rainy days before July due to Mongolian coldand low-swirl. In addition, the emission reduction policy started to effect since July. These two factors caused the concentration of $\mathrm{NO}_{2}$ generally was high as a result of lacking of photolysis. The concentrations of primary pollutants, $\mathrm{SO}_{2}$ and $\mathrm{NO}_{2}$, have significant falling with the implementation of emission reduction policy, particularly during the Olympic Games period.

\subsubsection{Diurnal variation of pollutants in different monitoring sites}

Fig. 6 presents the average diurnal variations of $\mathrm{SO}_{2}, \mathrm{NO}_{2}, \mathrm{O}_{3}$, and $\mathrm{PM}_{10}$ at different monitoring sites in different stages. The average diurnal variation curves of urban site (Fig. 6a, IRSA) and suburban site (Fig. 6b, YT) show that the concentration of $\mathrm{PM}_{10}$ only changed slightly, and the $\mathrm{PM}_{10}$ concentration of IRSA site is higher than that of YT site. The $\mathrm{PM}_{10}$ concentration measured in IRSA site was found decreasing continuously from Jul. 20 $0^{\text {th }}$ (The alternative day-driving scheme starting date) to September. The sharpest decreasing occurred between 01:00 12:00, and the $\mathrm{PM}_{10}$ concentration average diurnal variations at other stages were nearly equal. The $\mathrm{PM}_{10}$ concentration measured at YT site had a significant decline in September than before, and the main difference happened between 02:00 10:00. The average difference between urban and suburban changed from $50 \%$ of Jul. $1^{\text {st }}-$ Jul. $19^{\text {th }}$ to $25 \%$ of Sept. $6^{\text {th }}-$ Sept. $17^{\text {th }}$.

The measured $\mathrm{NO}_{2}$ concentration in all the monitor sites exhibited lower value from Jul. $20^{\text {th }}$ to Aug. $24^{\text {th }}$. The diurnal variation has an obvious double-peak. The first peak appeared at 05:00 09:00, suggesting that it may be related with local traffic emission and human activity. The second peak came out at 19:00 22:00, and this is originated from concentration accumulation due to atmospheric inversion effects of near-ground atmosphere and lack of photolysis in the night.

The comparison of $\mathrm{NO}_{2}$ diurnal variations in different monitoring sites showed that the concentration of $\mathrm{NO}_{2}$ in Capital Airport (CA) changed very little. This is reasonable when considering the large number of air flights every day, and the effect of alternative daydriving scheme is relative small. The measured $\mathrm{NO}_{2}$ concentration in July is much lower than that of June, and there is no clear peak value in the morning. The $\mathrm{NO}_{2}$ concentration of all sites during Sept. $6^{\text {th }}$-Sept. 16 th $^{\text {th }}$ increased a little bit compare with previous measurements, especially at around 19:00 in Capital Airport and 21:00 in IRSA.

The $\mathrm{NO}_{2}$ concentrations were found to decrease most in IRSA and CA sits from the average diurnal variation of $\mathrm{SO}_{2}$. The intermittent $\mathrm{SO}_{2}$ peaks appeared in $\mathrm{YT}$ site (16:00) before applying alternative day-driving scheme and YP site (10:00) during Jul. $1^{\text {st }}-$ Jul. 19th. The $\mathrm{NO}_{2}$ average diurnal variations generally showed single peak, and only YP and YT sites showed double-peak. The $\mathrm{NO}_{2}$ concentration is higher during the night-time in urban sites, while high $\mathrm{NO}_{2}$ concentration was found in other sites, e.g., YT and YP sites were found to have peak value between 07:00 09:00. 


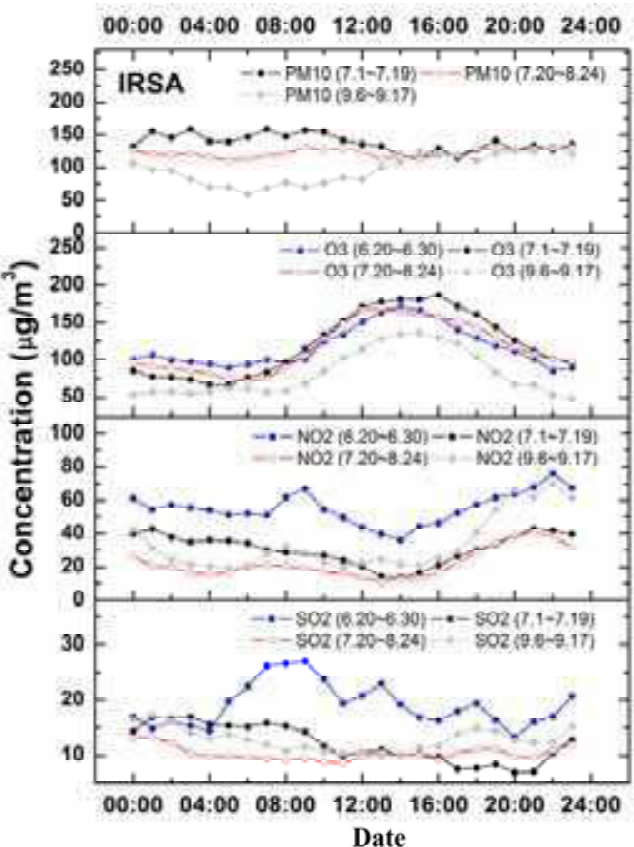

(a)

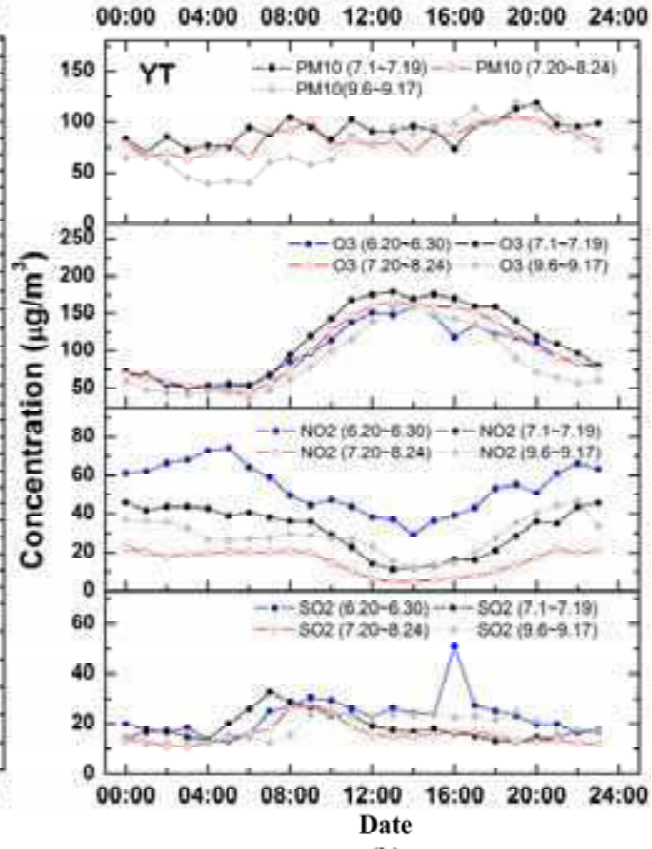

(b)

00:00 $04: 00 \quad 08: 00 \quad 12: 00 \quad 16: 00 \quad 20: 00 \quad 24: 00$

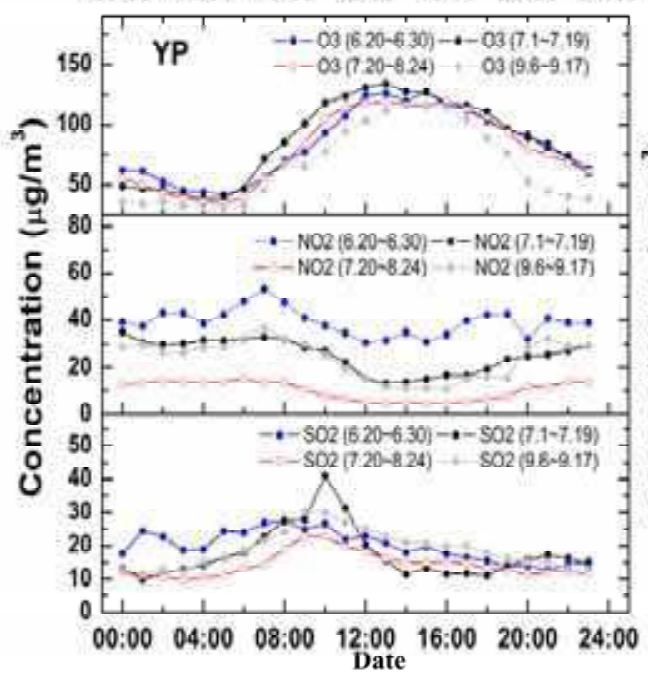

(c)
00:00 04:00 08:00 12:00 16:00 20:00 24:00

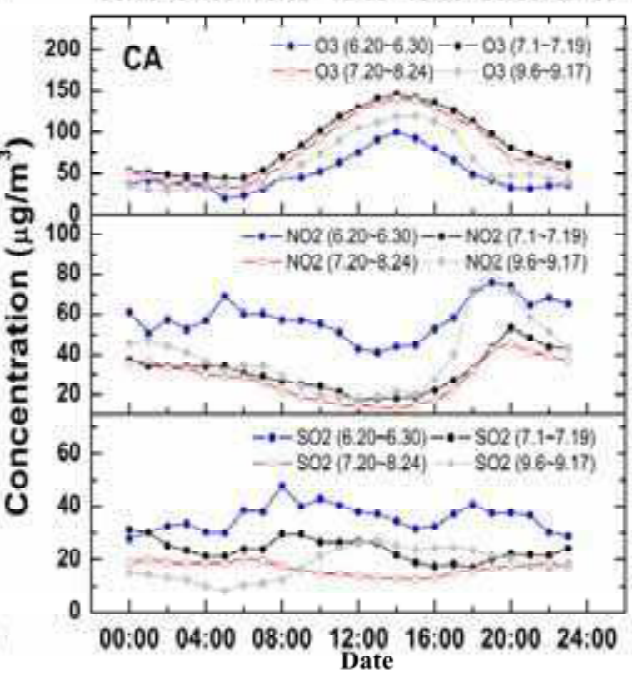

(d)

Fig. 6. Average diurnal patterns of $\mathrm{SO}_{2}, \mathrm{NO}_{2}, \mathrm{O}_{3}$ and $\mathrm{PM}_{10}$ in 4 monitoring stations

In contrast with $\mathrm{NO}_{2}$ and $\mathrm{SO}_{2}$, the measured $\mathrm{O}_{3}$ concentration increased somewhat at the beginning of applying alternative day-driving scheme. This can be explained by that $\mathrm{O}_{3}{ }^{\prime} \mathrm{s}$ originate in Beijing is basically controlled by VOCs. The decreasing of NOx resulted in local 
$\mathrm{O}_{3}$ 's consumption declination too, thus caused the increasing of $\mathrm{O}_{3}$ concentration. The statistic data after Jul. 20 th demonstrated that the $\mathrm{O}_{3}$ concentration decreased continuously. $\mathrm{O}_{3}$ concentration exhibits typical diurnal variation pattern, that is, the peak value appeared in the daytime, while the concentration became lower due to the reaction with NO. Measurements in urban sites showed that the $\mathrm{O}_{3}$ concentrations in Jul. 20th - Aug. 24 $4^{\text {th }}$ are comparable to that of June, but slightly lower. The peak $\mathrm{O}_{3}$ concentration appeared earlier from 16:00 of Jul. $1^{\text {st }}-$ Jul. 19th to 13:00 of Jul. 20th - Aug. $4^{\text {th }}$, while the peak appeared time from Sept. 6th - Sept. 17th is almost the same as that the beginning of alternative day-driving scheme and the difference between peak and valley values became smaller and smaller. $\mathrm{O}_{3}$ concentrations measured in YP and YT sites gave apparent double-peak features, where the first peak appeared around 13:00, and the second peak appeared around 16:00. The second peak probably is related with $\mathrm{O}_{3}{ }^{\prime} \mathrm{s}$ regional transport. Although YT site is far from urban area, $\mathrm{O}_{3}$ concentration was found to increase at the beginning stage of alternative daydriving scheme, but it became much lower afterwards, and the second peak became not so obvious. We found the same trend for $\mathrm{O}_{3}$ in Capital Airport, whose peak value appeared at around 14:00. The maximum concentration of $\mathrm{O}_{3}$ during Jul. $1^{\text {st }}$ - Jul. 19th increased by nearly $40 \mu \mathrm{g} / \mathrm{m}^{3}$ compare with that of June, and become a little lower afterwards.

\subsubsection{Observation of pollutants regional transport}

We will take the measured data of Aug. $8^{\text {th }}$ in four sites as an example to investigate the effect of the regional transport in southwest direction. $\mathrm{SO}_{2}$ and $\mathrm{O}_{3}$ were chosen as tracer pollutants. Fig. 7 shows the air mass backward trajectory at $200 \mathrm{~m}, 500 \mathrm{~m}$, and $1000 \mathrm{~m}$ heights in 24 hours using HYSPLIT model, where the star labeled the location of IRSA. One can find from Fig. 7 that the main wind direction is southwest, and the air mass transportation is from southwest (YP) to northeast (IRSA).

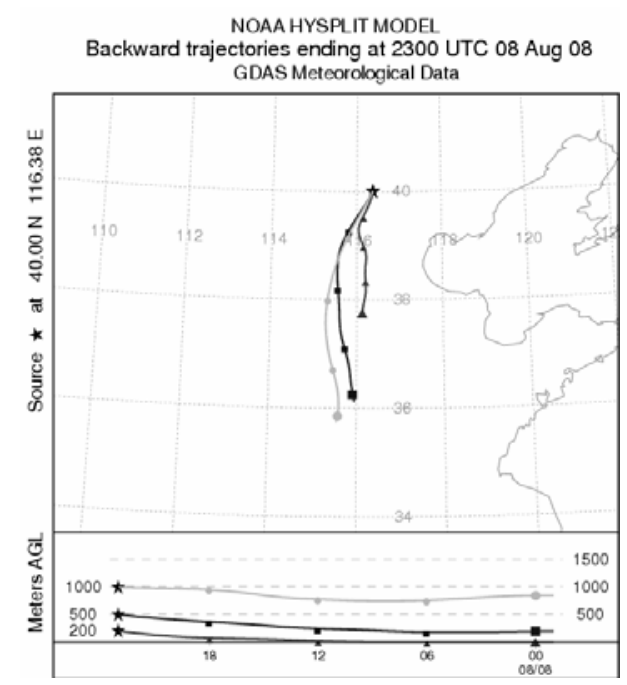

Fig. 7. Air trajectories for different altitudes of Aug. 8th, 2008

Fig. 8 presents the diurnal variations of $\mathrm{SO}_{2}$ and $\mathrm{O}_{3}$ on Aug. $8^{\text {th }}, 2008$. The YP monitor site got $\mathrm{SO}_{2}$ peak value at 12:00 first, and then the peak values were found in YT, IRSA, and CA 
sites at 13:00, 14:00, and 15:00, respectively. The time gap between the peak values is about 1 hour. $\mathrm{SO}_{2}$ was found to move from southwest (YP) to northwest (IRSA, CA). Same as $\mathrm{SO}_{2}$, the $\mathrm{O}_{3}$ peak value was found in YP site (12:00), and then YT, IRSA, and CA sites. The delay between peaks is about 1 hour as well. The $\mathrm{O}_{3}$ concentration of YP site was found to be the lowest, and keep at 125-128 $\mu \mathrm{g} / \mathrm{m}^{3}$ level during 12:00-16:00, and lowered a little bit at nighttime, but the second clear peak was found after 21:00. YT and IRSA sites then found $\mathrm{O}_{3}$ concentration peak values during night-time at 22:00 and 23:00, respectively. These peak values may be related with pollutants regional transport. Such findings are consistent with the $\mathrm{SO}_{2}$ vertical column density measurements of MAX-DOAS.

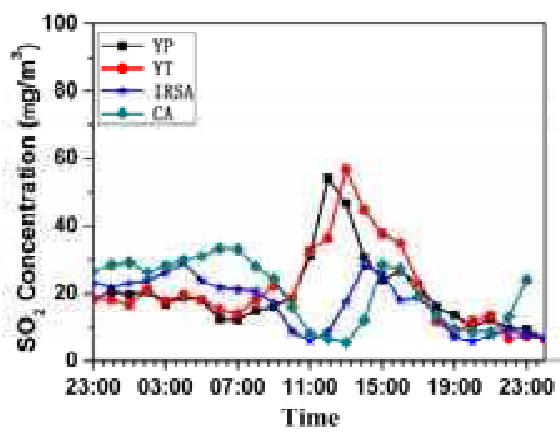

(a)

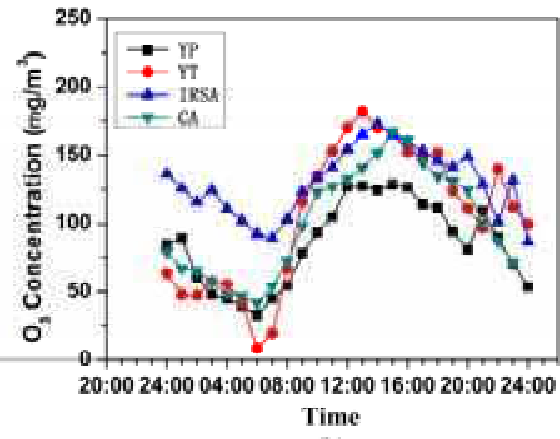

(b)

Fig. 8. Diurnal variation of $\mathrm{SO}_{2}(\mathrm{a})$ and $\mathrm{O}_{3}$ (b) measured at 4 monitoring stations on Aug. 8th, 2008

\subsubsection{Comparison of pollutants concentration in different monitoring sites}

Here we present the diurnal averages of $\mathrm{PM}_{10}, \mathrm{SO}_{2}$, and $\mathrm{NO}_{2}$ concentration; the maximum hourly average concentration of $\mathrm{O}_{3}$ measured during Jun. 20 $0^{\text {th }}$ - Sept. 22nd in every monitoring site. Table 1 gives the concentrations of conventional pollutants, $\mathrm{PM}_{10}, \mathrm{SO}_{2}, \mathrm{NO}_{2}$ and $\mathrm{O}_{3}$, measured at different stages between June and September, 2008, where diurnal averages value were used for $\mathrm{PM}_{10}, \mathrm{SO}_{2}$, and $\mathrm{NO}_{2}$, while maximum hourly average values were used for $\mathrm{O}_{3}$. PM10: Fig. 9 presents the comparison of $\mathrm{PM}_{10}$ daily average concentration and statistical diurnal average concentration measured in IRSA and YT sites. Since IRSA site is close to the Bird's Nest and there are more human activities around the site, the concentration measured here was about $40 \%$ higher than that of YT site. The $\mathrm{PM}_{10}$ variation patterns in two sites are similar, and high concentration was found in two periods (Jul. 24 $4^{\text {th }}-$ Jul. 28 $8^{\text {th }}$ Aug. $4^{\text {th }}-$ Aug. 7 th). The respirable particulate matters accumulate due to the static stable weather and resulted in the $\mathrm{PM}_{10}$ concentration in IRSA exceeded the National Atmospheric Environmental Level II standard $\left(150 \mu \mathrm{g} / \mathrm{m}^{3}\right)$. We can see from Table 1 that the $\mathrm{PM}_{10}$ concentration of IRSA which located in urban area was larger than that of YT, and the reductions were $12.1 \%$ and $9.9 \%$, respectively. The measurements at urban sites showed that of $\mathrm{PM}_{10}$ concentration had a big growth in September.

$\mathrm{SO}_{2}$ : Fig. 10 presents the variation of $\mathrm{NO}_{2}$ daily average concentration and the contrast of statistical average concentration. No concentration over standard was found during the whole campaign. Since there were lots of precipitations between Jun. $2^{\text {th }}$ and Jul. $4^{\text {th }}$, the concentrations of pollutants like $\mathrm{NO}_{2}$ were relatively low due to wet sedimentation. The $\mathrm{NO}_{2}$ concentration of $\mathrm{CA}$ was higher than other sites, and the highest concentration 


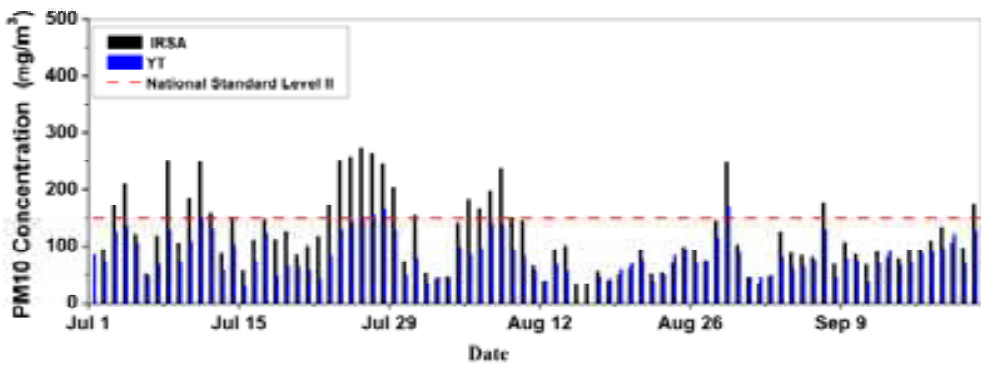

(a)

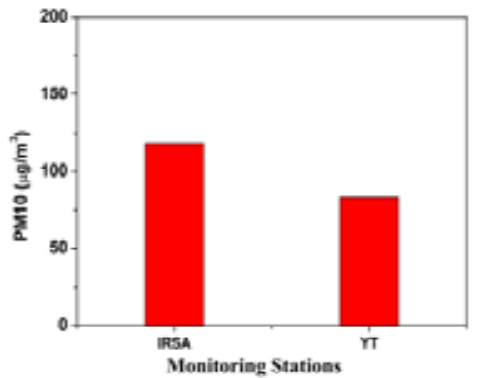

(b)

Fig. 9. Diurnal mean variation (a) and statistical average daily mean of $\mathrm{PM}_{10}$ concentration (b) during the campaign

\begin{tabular}{|c|c|c|c|c|c|c|c|c|c|}
\hline \multirow[b]{2}{*}{ Site } & \multirow[b]{2}{*}{$\begin{array}{c}\text { Pollutants } \\
\left(\mu \mathrm{g} / \mathrm{m}^{3}\right)\end{array}$} & \multicolumn{8}{|c|}{ Measurement Periods } \\
\hline & & June & $\begin{array}{l}7.1- \\
7.19\end{array}$ & $\begin{array}{l}7.20- \\
8.24\end{array}$ & 8.8-8.24 & 9.6-9.17 & $\begin{array}{c}\text { 7.1- } \\
\text { 7.19/June } \\
\text { Decease }\end{array}$ & $\begin{array}{c}7.20-8.24 / 7.1- \\
7.19 \\
\text { Decrease }\end{array}$ & $\begin{array}{c}\text { 9.6-9.17/8.8- } \\
8.24 \\
\text { Decrease }\end{array}$ \\
\hline \multirow{4}{*}{ YT } & $\mathrm{NO}_{2}$ & 51.7 & 32.0 & 15.6 & 13.9 & 28.6 & $38.1 \%$ & $51.3 \%$ & $-105.6 \%$ \\
\hline & $\mathrm{SO}_{2}$ & 22.7 & 18.2 & 15.6 & 11.4 & 18.5 & $19.8 \%$ & $14.3 \%$ & $-61.7 \%$ \\
\hline & $\mathrm{O}_{3}$ & 176.1 & 200.4 & 177.8 & 155.9 & 166.1 & $-13.8 \%$ & $11.3 \%$ & $-4.03 \%$ \\
\hline & PM10 & & 90.0 & 81.3 & 66.3 & 75.9 & & $9.6 \%$ & $-14.5 \%$ \\
\hline \multirow{4}{*}{ IRSA } & $\mathrm{NO}_{2}$ & 54.5 & 33.2 & 21.9 & 18.7 & 32.8 & $39.1 \%$ & $34.0 \%$ & $-75.8 \%$ \\
\hline & $\mathrm{SO}_{2}$ & 19.4 & 12.3 & 10.2 & 7.7 & 15.1 & $36.6 \%$ & $17.1 \%$ & $-97.0 \%$ \\
\hline & $\mathrm{O}_{3}$ & 185.0 & 208.3 & 179.7 & 136.8 & 144.7 & $-12.6 \%$ & $13.7 \%$ & $-2.5 \%$ \\
\hline & PM10 & & 139.0 & 122.2 & 80.8 & 94.4 & & $12.1 \%$ & $-16.9 \%$ \\
\hline \multirow{3}{*}{$\mathbf{Y P}$} & $\mathrm{NO}_{2}$ & 37.8 & 26.6 & 10.3 & 10.1 & 24.1 & $29.6 \%$ & $61.3 \%$ & $-142.5 \%$ \\
\hline & $\mathrm{SO}_{2}$ & 19.1 & 18.4 & 14.4 & 12.6 & 18.8 & $3.7 \%$ & $21.7 \%$ & $-50.0 \%$ \\
\hline & $\mathrm{O}_{3}$ & 145.4 & 157.4 & 135.7 & 111.6 & 125.0 & $-8.3 \%$ & $13.8 \%$ & $-8.9 \%$ \\
\hline \multirow{3}{*}{ CA } & $\mathrm{NO}_{2}$ & 57.8 & 32.5 & 27.5 & 28.4 & 20.5 & $43.8 \%$ & $15.4 \%$ & $-35.8 \%$ \\
\hline & $\mathrm{SO}_{2}$ & 37.2 & 25.1 & 16.8 & 10.7 & 18.1 & $32.5 \%$ & $33.1 \%$ & $-68.3 \%$ \\
\hline & $\mathrm{O}_{3}$ & 106.0 & 157.6 & 153.7 & 124.1 & 129.7 & $-48.7 \%$ & $2.5 \%$ & $-3.3 \%$ \\
\hline
\end{tabular}

Table 1. Concentrations of routine pollutants at 4 monitoring stations from June to September, 2008 
measured on Jun. 27th was $56.8 \mu \mathrm{g} / \mathrm{m}^{3}$. The average concentrations of each site was found to decrease more than that before implementation of alternative day-driving scheme, especially for IRSA site where the reduction up to $35 \%$. Due to the continuous rain showers between Aug. $8^{\text {th }}$ and Aug. 15th, the $\mathrm{NO}_{2}$ concentrations in several sites were found decreased considerably because of $\mathrm{NO}_{2}$ purge. CA's $\mathrm{SO}_{2}$ concentration decreased significantly during the period of Jul. 20th - Aug. $24^{\text {th }}$ compare with the beginning of the alternative day-driving scheme. After the Olympic Games, the $\mathrm{SO}_{2}$ concentrations measured in all sites were higher than that of August. Specifically, the concentration of $\mathrm{SO}_{2}$ was found to increase by $97 \%$ (Table 2). One can find the CA statistical diurnal average concentration is the highest in all the sites, followed by YT, YP and IRSA. This can be explained by there are more flights in CA area.
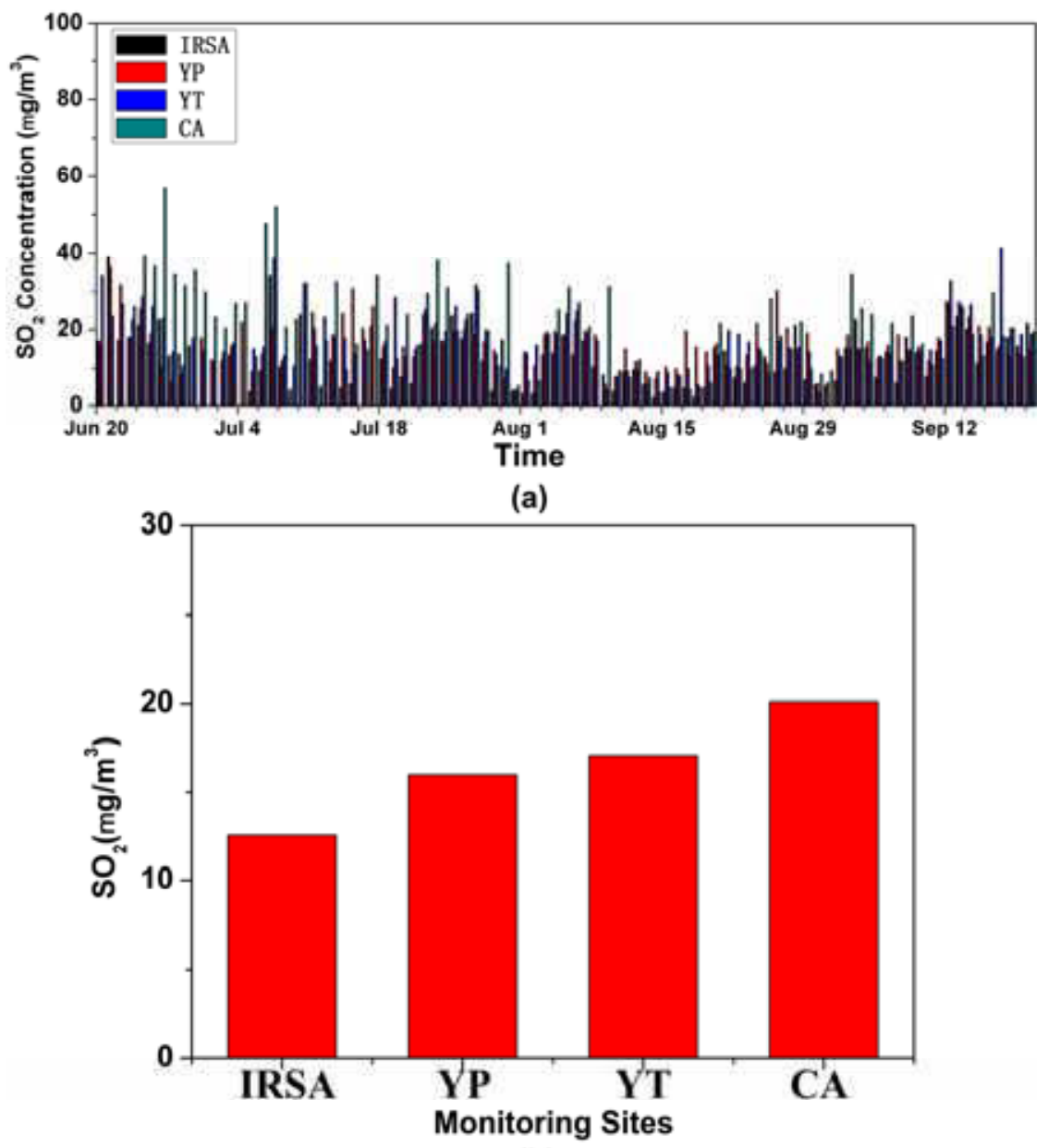

(b)

Fig. 10. Daily mean variation and statistical average daily mean of $\mathrm{SO}_{2}$ during the whole campaign 
$\mathrm{NO}_{2}$ : Fig. 11 gives the $\mathrm{NO}_{2}$ diurnal average concentration and the comparison of statistical average concentration. Same as $\mathrm{SO}_{2}$, there was no concentration over standard was found. There were lots of rains between Jun. 25 th and Jul. $1^{\text {st }}$. $\mathrm{NO}_{2}$ accumulated due to lack of photolysis in this period, and resulted in high concentration during Jun. 27th and Jun. 29th As the weather changed and photochemical activity was enhanced after Jul. 1st, the $\mathrm{NO}_{2}$ was decomposed through photolysis and $\mathrm{NO}_{2}$ concentrations at all sites decreased. The static weather pollutants accumulated on Jul. 29th and Aug. 1st-Aug. $8^{\text {th }}$ resulted in high $\mathrm{NO}_{2}$ concentration. With the coming of Olympic Games opening ceremony, the $\mathrm{NO}_{2}$ concentration in CA and IRSA increased gradually, but decreased abruptly on Aug. $8^{\text {th }}$. Same as that of $\mathrm{SO}_{2}, \mathrm{NO}_{2}$ concentration in BA site was higher than other sites. With the implementation of emission reduction policy, $\mathrm{NO}_{2}$ concentration in YP and YT decreased noticeably during Jul. $20^{\text {th }}$ to Aug. $24^{\text {th }}$. The concentration in all sites increased to some extent in September, especially in YP and YT sites, and the growths are 142\% and 105\%, respectively. Judged from statistical diurnal average concentration, CA and IRSA had a higher $\mathrm{NO}_{2}$ concentration due to human activity, then followed by YT and YP.

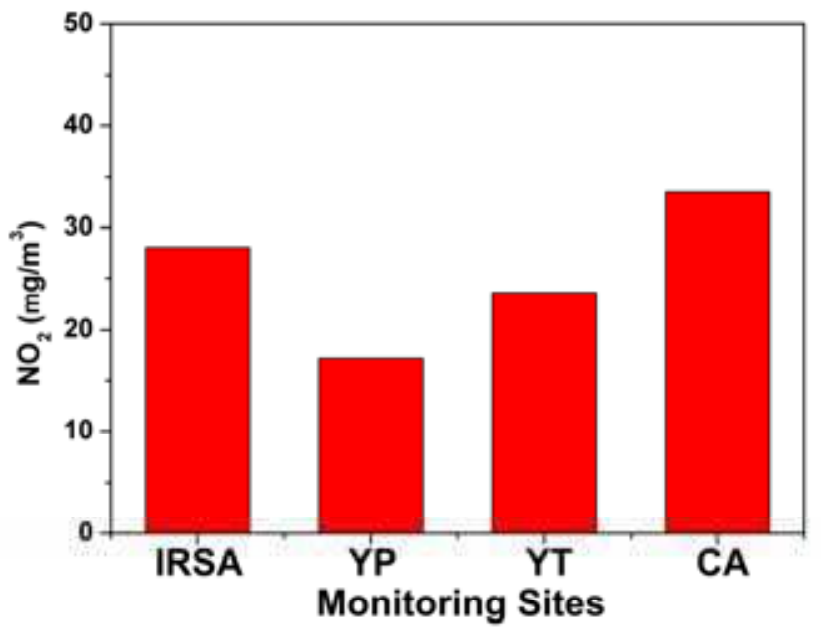

Fig. 11. Daily mean variation and statistical average daily mean of $\mathrm{NO}_{2}$ during the whole campaign

$\mathrm{O}_{3}$ : Fig. 12 gives the $\mathrm{O}_{3}$ diurnal hourly concentration and the comparison of statistical hourly maximum average concentration. As a result of rainy weather, the low photochemical activities led to low $\mathrm{O}_{3}$ concentration. The concentration exceeding standard happened mainly during the static stable weather period, and they are Jul. $11^{\text {th }}-\mathrm{Jul} .2^{\text {th }}$, and Aug. $2^{\text {nd }}-$ Aug. $6^{\text {th }}$. In particular, the $\mathrm{O}_{3}$ concentration in several sites increased at a rate of about $40 \%$ from Aug. $1^{\text {st }}$ to Aug. $6^{\text {th }}$ with the maximum happened on Aug. $3^{\text {rd }}$, and then decreased at a rate of $7 \% /$ day. From Aug. $8^{\text {th }}$ to the end of Olympic Games, $\mathrm{O}_{3}$ concentration measured in 4 sites meet the National Air Quality Standard Level II overall and were kept in a relative low level except on some days. From the statistical hourly average maximum concentration, YT site had the highest $\mathrm{O}_{3}$ concentration, followed by IRSA and CA, and YP had the lowest $\mathrm{O}_{3}$ concentration. 


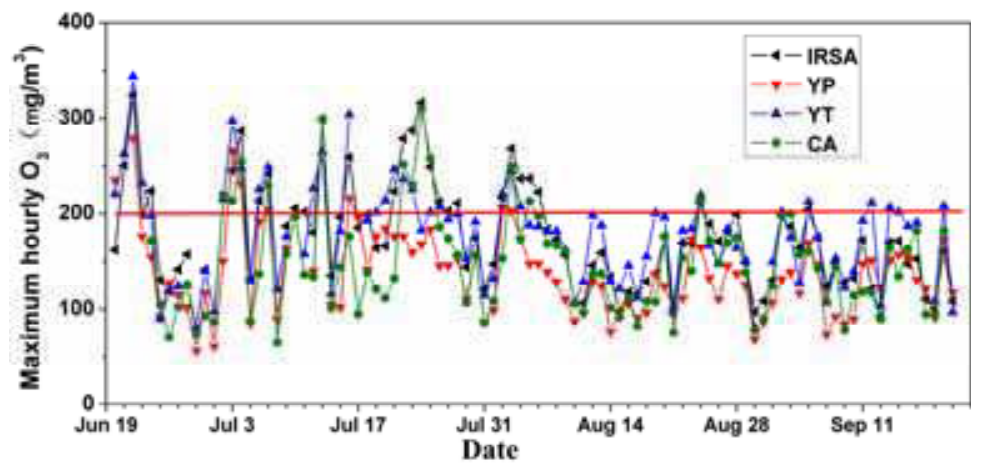

(a)

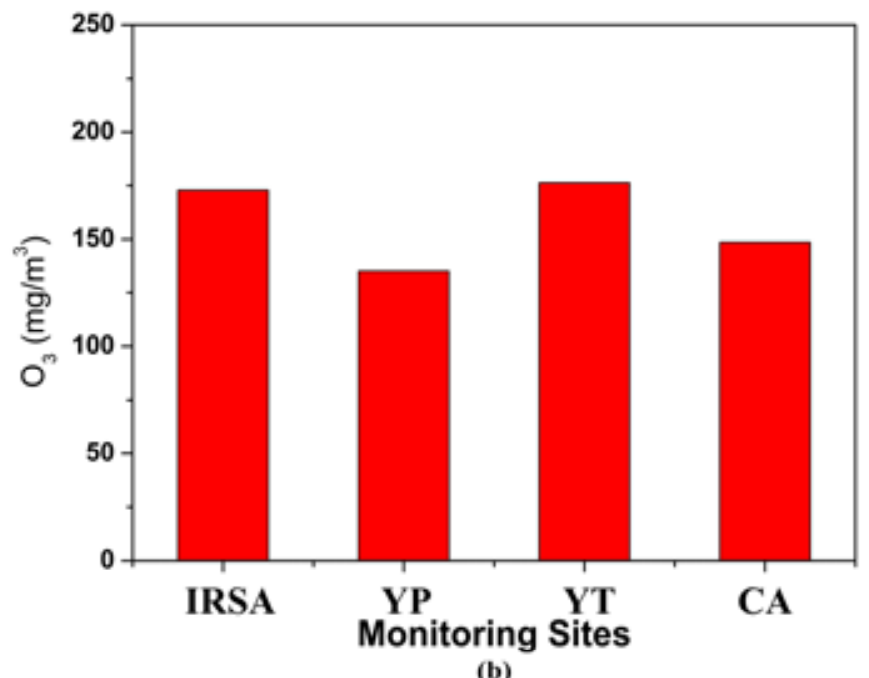

Fig. 12. Maximum hourly ozone concentrations on a daily basis and statistical average of the maximum hourly ozone during the whole campaign

The exceeding standard hourage of each site is shown in Fig. 20. One can find that $\mathrm{O}_{3}$ concentrations go beyond the standard on Jun. $2^{\text {nd }}$, Jul. $3^{\text {rd }}-\mathrm{Jul} .4^{\text {th }}$, Jul. $7^{\text {th }}$, and Jul. $16^{\text {th }}$. It is worth to mention that the period over standard in YP, YT and IRSA on Jun. 22nd was found to last up to 9 hours. With the implementation of pollution reduction policy, $\mathrm{O}_{3}$ concentration in YP decreased significantly. The $\mathrm{O}_{3}$ concentration in all sites meet the requirement of National Air Quality Standard Level II except $\mathrm{O}_{3}$ concentration of YT site exceeded the standard occasionally.

$\mathrm{SO}_{2}$ and $\mathrm{NO}_{2}$ concentrations were found to meet the National Air Quality Level II standard during the whole campaign. The $\mathrm{SO}_{2}$ and $\mathrm{NO}_{2}$ concentration declined in the first stage of alternative day-driving scheme (Jul. $1^{\text {st }}-\mathrm{Jul} .19^{\text {th }}$ ). The reduction of $\mathrm{NO}_{2}$ was far larger than that of $\mathrm{SO}_{2}$, and reduced up to $30 \%$ in all the sites, especially in CA site. All the pollutants concentration continue to decrease in the second stage (Jul. 20 $0^{\text {th }}-$ Aug. 24th), and $\mathrm{NO}_{2}$ concentration in YP site which is in suburban decreased most significantly and up to $60 \%$, 
then followed by $\mathrm{YT}$ site. The $\mathrm{SO}_{2}$ concentration in CA site decreased most drastically and up to $33 \%$.

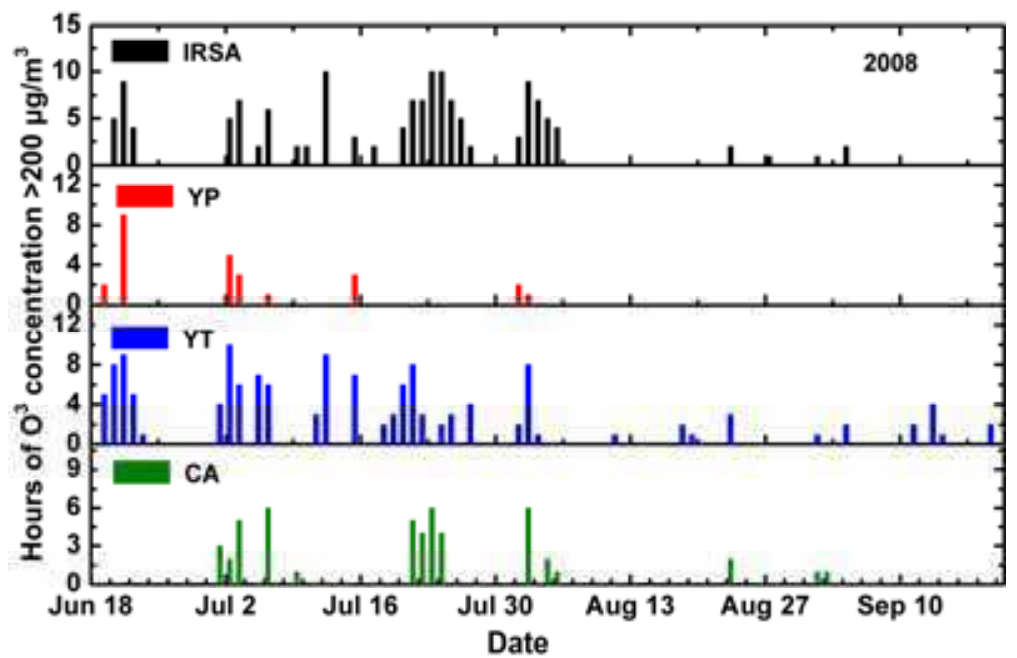

Fig. 13. Hourage of $\mathrm{O}_{3}$ exceeding standard

The $\mathrm{O}_{3}$ concentration was found to go up then go down at the beginning of the alternative day-driving scheme. This can be explained by that Beijing is located in the VOCs control area generated by $\mathrm{O}_{3}$. The reduction of NOx due to alternative day-driving scheme will cause $\mathrm{O}_{3}$ concentration to increase. Compare with June, $\mathrm{O}_{3}$ in CA site increase most significant and up to $48.7 \%$, and that of YT and IRSA increase by about $13 \%$. The regional transport existed due to the influence of the southwest wind. The YT and IRSA sites located in the downwind of YP site can find peak $\mathrm{O}_{3}$ in turn.

Since $\mathrm{PM}_{10}$ is more closely affected by human activities, the $\mathrm{PM}_{10}$ concentrations in monitoring sites in urban area were higher. The $\mathrm{PM}_{10}$ concentrations of IRSA which is in urban area were found to have more reduction than that of $\mathrm{YT}$ site during the Olympic Games period compare to the first stage, and decreased by $12.1 \%$ and $9.6 \%$, respectively.

When comparing the Olympic Games period with the first stage of emission reduction policy, $\mathrm{SO}_{2}, \mathrm{NO}_{2}, \mathrm{O}_{3}$, and $\mathrm{PM}_{10}$ concentrations in all monitoring sites decreased by $14 \%-33 \%$, $15 \%-6 \%, 2.5 \%-14 \%, 10 \%-12 \%$, respectively. But the concentrations of these pollutants increased during the Paralympic Games period.

\subsection{Comparison of $\mathrm{NO}_{2}$ measured by MAX-DOAS and OMI}

Fig. 14 presents the comparison of the tropospheric $\mathrm{NO}_{2}$ colmun density of MAX-DOAS and OMI from Jun. $1^{\text {th }}$ to Sept. $14^{\text {th }}$. The MAX-DOAS setup was installed close to the Bird's Nest. One can easily find the results of ground-basd MAX-DOAS are higher than that of OMI, and can up to 2.4 times on some days (Fig. 14a). This can be explained by spatial resolution difference between MAX-DOAS and OMI. The OMI's spatial resolution is $13 \times 24$ $\mathrm{km}^{2}$ whereas MAX-DOAS has much higher resolution. This means the results of OMI is the average of a large area including the urban and suburban area. We know that the $\mathrm{NO}_{2}$ of suburban area is much lower than that of urban area. This was validated by the average 
$\mathrm{NO}_{2}$ column density measured in 3 sites (Fig. 14b). Fig. 14b showed the column density ratio of MAX-DOAS to OMI decrease to 1.5 - 1.8 (Table 2). One can image that with more sites, the MAX-DOAS average will be close to OMI measurements.

\begin{tabular}{|c|c|c|c|}
\hline & $\begin{array}{c}\text { OMI } \\
\left(\mathbf{1 0 1 5} \mathbf{m o l e c} . / \mathbf{c m}^{2}\right)\end{array}$ & $\begin{array}{c}\text { MAX-DOAS } \\
\left.\mathbf{( 1 0 1 5} \mathbf{m o l e c} / \mathbf{c m}^{\mathbf{2}}\right)\end{array}$ & $\begin{array}{c}\text { Average } \\
\left.\mathbf{( 1 0 1 5} \mathbf{m o l e c} / \mathbf{c m}^{\mathbf{2}}\right)\end{array}$ \\
\hline June & 8.54 & 12.46 & 13.13 \\
\hline August & 7.81 & 15.91 & 14.36 \\
\hline September & 9.05 & 19.91 & 15.36 \\
\hline
\end{tabular}

Table 2. Comparison of monthly average between OMI and MAX-DOAS
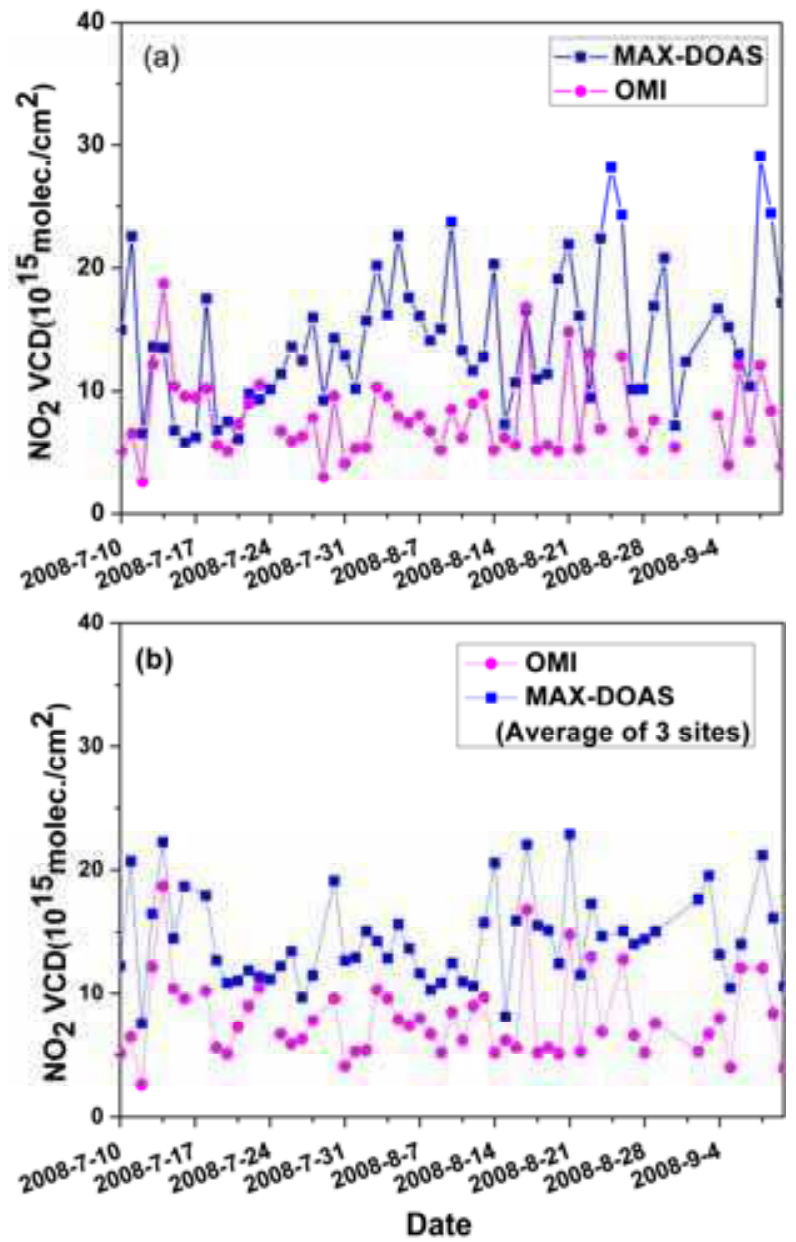

Fig. 14. Comparison between the results of OMI and MAX-DOAS,(a) is the result of comparison between OMI and MAX-DOAS near the Olympic venues, $(b)$ is comparison between OMI and the average of three sites, IRSA, CIS and YT, which are in the same pixel of OMI 
It is worth to mention that $\mathrm{Yu}(\mathrm{Yu}$ et al., 2010) also assessed the effect of the air quality ensuring measures during the game period using the tropospheric $\mathrm{NO}_{2}$ column density retrieved from Ozone Monitoring Instrument (OMI) onboard AURA satellite. About 40\% reduction in tropospheric $\mathrm{NO}_{2}$ column density over the Beijing area is obtained from the assessment during July to August, 2008, a key period of air quality ensuring measures for the Beijing 2008 Olympic Games.

\section{Conclusion}

China hosted XXIX Olympic and Paralympics Games in its capital, Beijing, from August to September of 2008. To improve the air quality during this period, extreme stringent pollutions control policies were applied to Beijing and its neighbouring provinces. A variety of optical remote sensing techniques were employed on the measurements of the air quality of Beijing at different stages of Olympic Games. The aerosol extinction coefficients and aerosol optical depth between August $7^{\text {th }}$ and August 25th were obtained using Raman LIDAR. Differential Optical Absorption Spectroscopy (DOAS) was utilized to evaluate the density of $\mathrm{SO}_{2}, \mathrm{NO}_{2}, \mathrm{O}_{3}$. The density of $\mathrm{SO}_{2}, \mathrm{NO}_{2}, \mathrm{O}_{3}$ from July $20^{\text {th }}$ to August $24^{\text {th }}$ were reduced by $14 \%-33 \%, 15 \%-61 \%$, and $2.5 \%-14 \%$, than that of July $1^{\text {st }}$ to July $19^{\text {th }}$, respectively. The troposphere $\mathrm{NO}_{2}$ column density acquired using multi-axis differential DOAS (MAXDOAS) was found to be much higher than that from OMI with a maximum factor of 2.4. $\mathrm{PM}_{10}$ was found to decline by $10 \%-12 \%$ during the Olympic Game period using TEOM. The results were compared with data from other groups using similar methods or different methods like satellite observations or air quality modelling system, and demonstrated the efficiency of pollution control measures to improve the air quality during the XXIX Olympic Games in 2008.

Using the optical remote techniques aforementioned along with other techniques like satellite observation, an integrated spatiotemporal monitoring system for regional complex air pollution was constructed. The results demonstrated the efficiency of pollution control measures in surrounding areas in improving air quality in Beijing. Optical remote sensing techniques were proved to be critical in air quality monitoring system.

\section{Acknowledgment}

The experimental and theoretical work done at AIOFM were supported by grants from National Science Foundation of China (40905010, 40805015), National High Technology Research and Development Program (2009AA063006), and Special Fund of Environmental Protection and Public Service (201109007).

\section{References}

Cermak, J., \& Knutti, R. (2009). Beijing olympics as an aerosol field experiment. Geophysical Research Letters, 36, L10806.

Chen, Z. Y., Liu, W. Q., Zhang, Y. J., Zhao, N. J., He, J. F., \& Ruan, J. (2009). Measurements of aerosol distribution by an elastic-backscatter lidar in summer 2008 in beijing. Chinese Optics Letters, 7, 753-755.

Duncan, B. N., Yoshida, Y., Olson, J. R., Sillman, S., Martin, R. V., Lamsal, L., et al. (2010). Application of omi observations to a space-based indicator of nox and voc controls on surface ozone formation. Atmospheric Environment, 44, 2213-2223. 
He, S. Z., Chen, Z. M., Zhang, X., Zhao, Y., Huang, D. M., Zhao, J. N., et al. (2010). Measurement of atmospheric hydrogen peroxide and organic peroxides in beijing before and during the 2008 olympic games: Chemical and physical factors influencing their concentrations. eburnal of Geophysical Research-Atmospheres, 115.

He, Y., Zhang, Y. J., Kan, R. F., Xia, H., Geng, H., Ruan, J., et al. (2009). Open-path online monitoring of ambient atmospheric co2 based on laser absorption spectrum. Spectroscopy and Spectral Analysis, 29, 10-13.

He, Y. B., Kan, R. F., Englich, F. V., Liu, W. Q., \& Orr, B. J. (2010). Simultaneous multi-laser, multi-species trace-level sensing of gas mixtures by rapidly swept continuous-wave cavity-ringdown spectroscopy. Optics Express, 18, 20059-20071.

Hou, Q., An, X. Q., Wang, Y., \& Guo, J. P. (2010). An evaluation of resident exposure to respirable particulate matter and health economic loss in beijing during beijing 2008 olympic games. Science of the Total Environment, 408, 4026-4032.

Huang, X. F., He, L. Y., Hu, M., Canagaratna, M. R., Sun, Y., Zhang, Q., et al. (2010). Highly time-resolved chemical characterization of atmospheric submicron particles during 2008 beijing olympic games using an aerodyne high-resolution aerosol mass spectrometer. Atmospheric Chemistry and Physics, 10, 8933-8945.

Jin, L., Gao, M. G., Liu, W. Q., Lu, Y. H., Zhang, Y. J., Wang, Y. P., et al. (2010). Application of sof-ftir method to measuring ammonia emission flux of chemical plant. Spectroscopy and Spectral Analysis, 30, 1478-1481.

Lackner, M. (2007). Tunable diode laser absorption spectroscopy (tdlas) in the process industries - a review. Reviews in Chemical Engineering, 23, 65-147.

Li, S. W., Liu, W. Q., Xie, P. H., Wang, F. S., \& Yang, Y. J. (2009). Real-time forecasting model for monitoring pollutant with differential optical absorption spectroscopy. Spectroscopy and Spectral Analysis, 29, 3057-3060.

Li, S. W., Liu, W. Q., Xie, P. N., Li, A., Qin, M., Peng, F. M., et al. (2008). Observation of the nighttime nitrate radical in hefei, china. eburnal of Environmental Sciences-China, 20, 45-49.

Li, Y., Shao, M., Lu, S. H., Chang, C. C., \& Dasgupta, P. K. (2010). Variations and sources of ambient formaldehyde for the 2008 beijing olympic games. Atmospheric Environment, 44, 2632-2639.

Liu, J. F., Mu, Y. J., Zhang, Y. J., Zhang, Z. M., Wang, X. K., Liu, Y. J., et al. (2009). Atmospheric levels of btex compounds during the 2008 olympic games in the urban area of beijing. Science of the Total Environment, 408, 109-116.

Liu, X. G., Zhang, Y. H., Jung, J. S., Gu, J. W., Li, Y. P., Guo, S., et al. (2009). Research on the hygroscopic properties of aerosols by measurement and modeling during carebeijing-2006. eburnal of Geophysical Research-Atmospheres, 114.

Lu, C. P., Liu, W. Q., Zhao, N. J., Liu, L. T., Chen, D., Zhang, Y. J., et al. (2010a). Influence of humidity on characteristic of laser-induced soil plasmas. Spectroscopy and Spectral Analysis, 30, 2885-2888.

Lu, C. P., Liu, W. Q., Zhao, N. J., Liu, L. T., Chen, D., Zhang, Y. J., et al. (2010b). Measurement and analysis of copper in soil using laser-induced breakdown spectroscopy. Spectroscopy and Spectral Analysis, 30, 3132-3135.

Luo, Y. H., Liu, W. Q., Bian, L. G., Lu, C. G., Xie, P. H., Si, F. Q., et al. (2011). The retrieval of ozone column densities by passive differential optical absorption spectroscopy during summer at zhongshan station, antarctic. Spectroscopy and Spectral Analysis, $31,456-460$. 
Mijling, B., van der A, R. J., Boersma, K. F., Van Roozendael, M., De Smedt, I., \& Kelder, H. M. (2009). Reductions of no2 detected from space during the 2008 beijing olympic games. Geophysical Research Letters, 36.

Movasaghi, Z., Rehman, S., \& Rehman, I. U. (2008). Fourier transform infrared (ftir) spectroscopy of biological tissues. Applied Spectroscopy Reviews, 43, 134-179.

Patashnick, H., \& Rupprecht, E. G. (1991). Continuous pm-10 measurements using the tapered element oscillating microbalance. eburnal of the Air \& Waste Management Association, 41, 1079-1083.

Shao, M., Lu, S. H., Liu, Y., Xie, X., Chang, C. C., Huang, S., et al. (2009). Volatile organic compounds measured in summer in beijing and their role in ground-level ozone formation. eburnal of Geophysical Research-Atmospheres, 114.

Shen, J. L., Tang, A. H., Liu, X. J., Kopsch, J., Fangmeier, A., Goulding, K., et al. (2011). Impacts of pollution controls on air quality in beijing during the 2008 olympic games. eburnal of Environmental Quality, 40, 37-45.

Shou-bin, F., Gang, T., Gang, L., Yu-hu, H., Jian-ping, Q., \& Shui-yuan, C. (2009). Road fugitive dust emission characteristics in beijing during olympics game 2008 in beijing, china. Atmospheric Environment, 43, 6003-6010.

Si, F. Q., Xie, P. H., Dou, K., Zhan, K., Liu, Y., Xu, J., et al. (2010). Determination of the atmospheric aerosol optical density by multi axis differential optical absorption spectroscopy. Acta Physica Sinica, 59, 2867-2872.

Simonich, S. L. M. (2009). Response to comments on "atmospheric particulate matter pollution during the 2008 beijing olympics". Environmental Science \& Technology, 43, 7590-7591.

Streets, D. G., Fu, J. S., Jang, C. J., Hao, J. M., He, K. B., Tang, X. Y., et al. (2007). Air quality during the 2008 beijing olympic games. Atmospheric Environment, 41, 480-492.

Tang, X. Y., Shao, M., Hu, M., Wang, Z. F., \& Zhang, J. F. (2009). Comment on "atmospheric particulate matter pollution during the 2008 beijing olympics". Environmental Science \& Technology, 43, 7588-7588.

Tang, Y. Y., Liu, W. Q., Kan, R. F., Zhang, Y. J., Liu, J. G., Xu, Z. Y., et al. (2010). Spectroscopy processing for the NO measurement based on the room-temperature pulsed quantum cascade laser. Acta Physica Sinica, 59, 2364-2368.

Vierling, K. T., Vierling, L. A., Gould, W. A., Martinuzzi, S., \& Clawges, R. M. (2008). Lidar: Shedding new light on habitat characterization and modeling. Frontiers in Ecology and the Environment, 6, 90-98.

Wang, B., Shao, M., Lu, S. H., Yuan, B., Zhao, Y., Wang, M., et al. (2010). Variation of ambient non-methane hydrocarbons in beijing city in summer 2008. Atmospheric Chemistry and Physics, 10, 5911-5923.

Wang, M., Zhu, T., Zheng, J., Zhang, R. Y., Zhang, S. Q., Xie, X. X., et al. (2009). Use of a mobile laboratory to evaluate changes in on-road air pollutants during the beijing 2008 summer olympics. Atmospheric Chemistry and Physics, 9, 8247-8263.

Wang, S. X., Zhao, M., Xing, J., Wu, Y., Zhou, Y., Lei, Y., et al. (2010). Quantifying the air pollutants emission reduction during the 2008 olympic games in beijing. Environmental Science \& Technology, 44, 2490-2496.

Wang, T., Nie, W., Gao, J., Xue, L. K., Gao, X. M., Wang, X. F., et al. (2010). Air quality during the 2008 beijing olympics: Secondary pollutants and regional impact. Atmospheric Chemistry and Physics, 10, 7603-7615.

Wang, T., \& Xie, S. D. (2009). Assessment of traffic-related air pollution in the urban streets before and during the 2008 beijing olympic games traffic control period. Atmospheric Environment, 43, 5682-5690. 
Wang, W. T., Primbs, T., Tao, S., \& Simonich, S. L. M. (2009). Atmospheric particulate matter pollution during the 2008 beijing olympics. Environmental Science \& Technology, 43, 5314-5320.

Wang, X., Westerdahl, D., Chen, L. C., Wu, Y., Hao, J. M., Pan, X. C., et al. (2009). Evaluating the air quality impacts of the 2008 beijing olympic games: On-road emission factors and black carbon profiles. Atmospheric Environment, 43, 4535-4543.

Westerdahl, D., Wang, X., Pan, X. C., \& Zhang, K. M. (2009). Characterization of on-road vehicle emission factors and microenvironmental air quality in beijing, china. Atmospheric Environment, 43, 697-705.

Winer, A. M., \& Biermann, H. W. (1994). Long pathlength differential optical-absorption spectroscopy (doas) measurements of gaseous hono, no2 and hcho in the california south coast air basin. Research on Chemical Intermediates, 20, 423-445.

Xin, J. Y., Wang, Y. S., Tang, G. Q., Wang, L. L., Sun, Y., Wang, Y. H., et al. (2010). Variability and reduction of atmospheric pollutants in beijing and its surrounding area during the beijing 2008 olympic games. Chinese Science Bulletin, 55, 1937-1944.

Xu, J., Xie, P. H., Si, F. Q., Dou, K., Li, A., Liu, Y., et al. (2010). Retrieval of tropospheric no2 by multi axis differential optical absorption spectroscopy. Spectroscopy and Spectral Analysis, 30, 2464-2469.

Xu, Z. Y., Liu, W. Q., Kan, R. F., Zhang, Y. J., Liu, J. G., Zhang, S. A., et al. (2010). Study on the arithmetic of absorbance inversion based on tunable diode-laser absorption spectroscopy. Spectroscopy and Spectral Analysis, 30, 2201-2204.

Yang, T., Wang, Z. F., Zhang, B., Wang, X. Q., Wang, W., Gbauidi, A., et al. (2010). Evaluation of the effect of air pollution control during the beijing 2008 olympic games using lidar data. Chinese Science Bulletin, 55, 1311-1316.

Yao, X. H., Xu, X. H., Sabaliauskas, K., \& Fang, M. (2009). Comment on "atmospheric particulate matter pollution during the 2008 beijing olympics". Environmental Science \& Technology, 43, 7589-7589.

Yu, H., Wang, P. C., Zong, X. M., Li, X., \& Lu, D. R. (2010). Change of no2 column density over beijing from satellite measurement during the beijing 2008 olympic games. Chinese Science Bulletin, 55, 308-313.

Zhang, L. F., Huang, Y. R., Shi, S. X., Zhou, L., Zhang, T., Dong, L. A., et al. (2010). Concentration and gas-particle partitioning of hexachlorobenzene in the ambient air before and after the beijing olympic games. Bulletin of Environmental Contamination and Toxicology, 85, 1-4.

Zhang, S. A., Dong, F. Z., Zhang, Z. R., Wang, Y., Kan, R. F., Zhang, Y. J., et al. (2009). Monitoring of oxygen concentration based on tunable diode laser absorption spectroscopy. Spectroscopy and Spectral Analysis, 29, 2593-2596.

Zhou, Y., Wu, Y., Yang, L., Fu, L. X., He, K. B., Wang, S. X., et al. (2010). The impact of transportation control measures on emission reductions during the 2008 olympic games in beijing, china. Atmospheric Environment, 44, 285-293.

Zhu, Y. W., Liu, W. Q., Xie, P. H., Dou, K., Qin, M., \& Si, F. Q. (2010). Monitoring and analysis for vertical profiles of air pollutants in boundary layer of beijing. Chinese eburnal of Geophysics-Chinese Edition, 53, 1278-1283. 


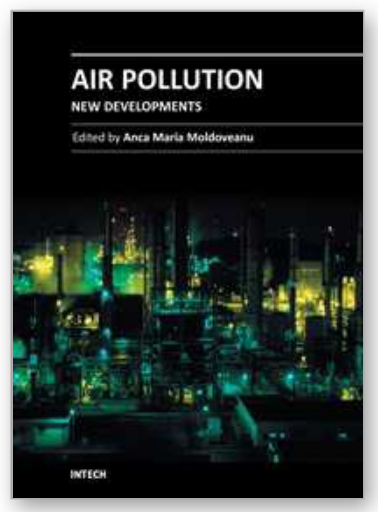

\author{
Air Pollution - New Developments \\ Edited by Prof. Anca Moldoveanu
}

ISBN 978-953-307-527-3

Hard cover, 324 pages

Publisher InTech

Published online 06, September, 2011

Published in print edition September, 2011

Today, an important issue is environmental pollution, especially air pollution. Due to pollutants present in air, human health as well as animal health and vegetation may suffer. The book can be divided in two parts. The first half presents how the environmental modifications induced by air pollution can have an impact on human health by inducing modifications in different organs and systems and leading to human pathology. This part also presents how environmental modifications induced by air pollution can influence human health during pregnancy. The second half of the book presents the influence of environmental pollution on animal health and vegetation and how this impact can be assessed (the use of the micronucleus tests on TRADESCANTIA to evaluate the genotoxic effects of air pollution, the use of transplanted lichen PSEUDEVERNIA FURFURACEA for biomonitoring the presence of heavy metals, the monitoring of epiphytic lichen biodiversity to detect environmental quality and air pollution, etc). The book is recommended to professionals interested in health and environmental issues.

\title{
How to reference
}

In order to correctly reference this scholarly work, feel free to copy and paste the following:

Wenqing Liu, Wei Huang, Pinhua Xie and Jianguo Liu (2011). Observation and Research on the Typical Atmosphere of Beijing Olympic Games by Optical Remote Sensing, Air Pollution - New Developments, Prof. Anca Moldoveanu (Ed.), ISBN: 978-953-307-527-3, InTech, Available from:

http://www.intechopen.com/books/air-pollution-new-developments/observation-and-research-on-the-typicalatmosphere-of-beijing-olympic-games-by-optical-remote-sensin

\section{INTECH}

open science | open minds

\section{InTech Europe}

University Campus STeP Ri

Slavka Krautzeka 83/A

51000 Rijeka, Croatia

Phone: +385 (51) 770447

Fax: +385 (51) 686166

www.intechopen.com

\section{InTech China}

Unit 405, Office Block, Hotel Equatorial Shanghai

No.65, Yan An Road (West), Shanghai, 200040, China 中国上海市延安西路65号上海国际贵都大饭店办公楼 405 单元

Phone: +86-21-62489820

Fax: $+86-21-62489821$ 
(C) 2011 The Author(s). Licensee IntechOpen. This chapter is distributed under the terms of the Creative Commons Attribution-NonCommercialShareAlike-3.0 License, which permits use, distribution and reproduction for non-commercial purposes, provided the original is properly cited and derivative works building on this content are distributed under the same license. 